\title{
Response of Potassium and Sulphur in Rabi oilseeds in Kymore Plateau and Satpura Hills Zone of Madhya Pradesh, India
}

\author{
A. K. Singh ${ }^{1^{*}}$, A. K. Tripathi ${ }^{2}$ and S. R. K. Singh ${ }^{3}$ \\ ${ }^{1}$ Jawaharlal Nehru Krishi Vishwa Vidyalaya, Krishi Vigyan Kendra, \\ Katni-483442, Madhya Pradesh, India, \\ ${ }^{2}$ Jawaharlal Nehru Krishi Vishwa Vidyalaya Krishi Vigyan Kendra, \\ Panna-488001, Madhya Pradesh, India \\ ${ }^{3}$ ICAR-Agricultural Technology Application Research Institute, Zone IX, JNKVV Campus, \\ Adhartal, Jabalpur-482004, Madhya Pradesh, India \\ *Corresponding author
}

\section{A B S T R A C T}

\begin{tabular}{l} 
K e y w o r d s \\
Productivity, \\
Improved cultivar, \\
Frontline \\
demonstrations, \\
Potassium, Sulphur, \\
Net return, \\
Technology gap, \\
Extension gap, \\
Technology index \\
\hline Article Info \\
Accepted: \\
10 March 2020 \\
Available Online: \\
10 April 2020 \\
\hline
\end{tabular}

\section{Introduction}

Next to the USA, China, and Brazil, India is the fourth leading oilseeds producing country in the world, harvesting about 32.1 million
Linseed and mustard are the most important prehistoric crops in the world, usually cultivated as major rabi oilseeds in India. The major constraints for low productivity are inadequate supply of nutrients and poor production practices. Technological demonstrations on linseed and mustard were conducted at 58 locations covering 24.4 ha area in participatory mode using improved linseed cultivar JLS 9, JLS 23 and mustard (pusa mahak) during 2007-08 to 2011-12. Line sowing was done after seed inoculation with azotobactor and PSB and soil test based NPK and sulphur doses were applied @ 60:40:20:40 $\mathrm{kg} \mathrm{ha}^{-1}$. To prevent the crop from weed infestation pre-emergence herbicide was applied through flat fan nozzle knapsack sprayer after sowing in both the crops. Average seed yield of 1035.67 and $1187 \mathrm{~kg} \mathrm{ha}^{-1}$ was recorded in improved cultivars under the technological frontline demonstrations of linseed and mustard respectively which was 66.68 and 86.2 percent higher over local check i.e. farmers' practice (621.33 and $\left.637.5 \mathrm{~kg} \mathrm{ha}^{-1}\right)$. The additional seed yield of linseed and mustard (414.33 and $\left.549.5 \mathrm{~kg} \mathrm{ha}^{-1}\right)$ obtained with improved practice was correspondent to 50 and 84 percent of the farmers' practice yield recorded in the respective crops which largely attributed to optimum potassium and sulphur application. The economic analysis of the frontline demonstrations on linseed and mustard gave the additional average net return of Rs. 11032.67 and $13886 \mathrm{ha}^{-1}$ was obtained with an incremental benefit cost ratio of 1.06 and 1.45 over the farmers' practice. The technology gap calculated in linseed and mustard showed the average yield gap of 114.33 and $563 \mathrm{~kg} \mathrm{ha}^{-1}$ respectively which was close to the cultivars' potential with 9.94 and 32.17 percent technology index in the frontline demonstrations. The average extension gap in the seed yield was observed 414.33 and $549.5 \mathrm{~kg} \mathrm{ha}^{-1}$ in linseed and mustard respectively. 
are the primary source of vegetable oils in the country, which are largely grown under rainfed condition over an area of about 26 million ha. Among these, soybean (34\%), groundnut $(27 \%)$, rapeseed \& mustard $(27 \%)$ contributes to more than $88 \%$ of total oilseeds production and $>80 \%$ of vegetable oil with major share of mustard (35\%), soybean (23\%) and groundnut $(25 \%)$. In addition to nine primary oilseeds, 03 million tonnes of vegetable oil is being harnessed from secondary sources like cottonseed, rice bran, coconut, Tree Borne Oilseeds (TBOs) and Oil Palm (Ag. Statistics 2017).

The per capita consumption of vegetable oil likely to rise to $16.38 \mathrm{~kg} \mathrm{ha}^{-1}$ in 2020 over $14.57 \mathrm{~kg} \mathrm{ha}^{-1}$ in 2015. This adds up to vegetable oil requirement of 21.8 million tonnes in 2020 over 2015 which was 18.3 million tones. Presuming an average oil recovery of 30.00 per cent from major oilseeds and proportion of different oilseeds in the year 2020, the country will need to produce at least 66.0 million tonnes per annum. Provided that the oilseeds production of 30 million tonnes in 2007-08, the country will need to almost double the oilseeds production in the next 12 years requiring an annual growth rate of about 6.00 per cent (Hegde, 2009).

Rapeseed and mustard are the third most important edible oilseed crops of the world after soybean and oil palm. In India, rapeseed $\&$ mustard and linseed occupy an area of 6.19 and 0.28 million ha with the production of 7.39 and 0.14 million tones and yield is 1190 and $490 \mathrm{~kg} \mathrm{ha}^{-1}$ respectively. Among the Rabi oilseed crops in India, rapeseed-mustard occupies the first position followed by linseed in areas as well as production. Mustard contributes $24.1 \%$ to the total oilseed production, grown mainly in states of Madhya Pradesh, Rajasthan, Maharashtra, Karnataka, Uttar Pradesh, Tamil Nadu, Haryana and
West Bengal. The average National productivity of mustard needs to be enhanced up to $2562 \mathrm{~kg} \mathrm{ha}^{-1}$ by 2030 for ensuring selfsufficiency in edible oil (DRMR, 2011). India is the second largest $(21.21 \%)$ linseed growing country in the world after Canada and production-wise it ranks fourth $(8.20 \%)$ in the world after Canada $(40.51 \%)$, China $(18.68 \%)$, and USA (10.89\%).

Madhya Pradesh is a leading state in oilseed cultivation in the country. The state has the area of 69.86 lakh ha with the production of 69.48 lakh tones and the average yield is 1177 $\mathrm{kg} \mathrm{ha}^{-1}$. The state has nine percent of the total area under rabi/summer oilseeds and contributes 8.5 percent production to the Nation with the average yield of $970 \mathrm{~kg} \mathrm{ha}^{-1}$.

Mustard is nutritionally very rich and its oil content varies from 37-49\%. Mustard belongs to the family of Cruciferae. Crucifers containing high amounts of glucosinolates have a high sulfur demand (Rathore et al., 2015). Linseed also known as flax is a dual purpose (oilseed and fiber) crop, grown for both seed as well as fiber for the manufacture of linen. Its seed contains a reasonable oil content which varies from 33 to 47 percent according to variety. The oil is edible and also due to its quick drying property, it is used for the preparation of printing ink, oil cloth, soap, paints, varnishes, and waterproof fabrics. Its oilcake is a most valuable feeding cake perhaps the most favorite cattle feed. It is rich in protein (36 percent) fed to both milch and fattening animals. Besides feeding cattle it is also used as organic manure as it is rich in nutrients i.e. $\mathrm{N}$ nearly 5 percent, $\mathrm{P} 1.4$ percent and $\mathrm{K} 1.8$ percent. The flax seeds contain 23\% 18:3 Omega-3 fatty acids (mostly ALA) and $6 \%$ 18:2 Omega-6 fatty acids. Its oil contains 53\% 18:3 Omega-3 fatty acids (mostly ALA) and 13\% 18:2 Omega-6 fatty acids. One of the main components of flax is lignan (up to 800 times more than other plant 
foods) which has plant estrogen as well as antioxidants.

Continuous use of inadequate production technologies by farmers may not sustain soil fertility, productivity and profitability of rabi oilseeds largely mustard and linseed, hence it is needed to identify the major current constraints limiting productivity of these crops in India. However, use of improved production technologies is required to improve the soil health as well as to attain sustainable crop productivity. Hence, use of improved production technologies offers a great scope for increasing productivity and profitability of these crops. The remarkable yield enhance may be obtained with adoption of improved technologies such as selection of improved varieties, balanced use of nutrients, adequate weed management practices and proper plant protection measures.

Several biotic, abiotic, and socio-economic constraints inhibit exploitation of the yield potential and these needs to be addressed. The utmost limitations in increasing the productivity of the crop are inadequate supply of nutrients and poor production practices are poor in native fertility (Singh and Khan, 2003). Potassium is one of the three major essential nutrient elements required by plants. Potassium exists in mobile ionic form and its function appears to be primarily catalytic in nature. Plants absorb potassium in larger amounts than any nutrient except nitrogen. Sulphur is the fourth most important nutrient after nitrogen, phosphorus and zinc for Indian agriculture. It is also needed for the synthesis of other metabolites, including coenzyme A, biotin, thiamin or vitamin $\mathrm{B}_{1}$ and glutathione. Sulphur occurs in volatile compounds responsible for the characteristic taste and smell of plants in the mustard and onion families. It is also involved in the formation of chlorophyll, glucosides and glucosinolates (mustard oils), activation of enzymes and sulphydryl (SH-) linkages that are the source of pungency in oilseeds.

Mustard is responsive to sulphur in comparison to other crops. Sulfur fertilization has also been shown to increase the oil content in seeds of rapeseed-mustard (Singh et al., 2015). Sulphur is the key component of balanced nutrient application for higher yields and superior quality produce of mustard. Sulphur plays a vital role in the synthesis of amino acids, chlorophyll and certain vitamins in mustard plant (Rathore et al., 2015).

In view of these facts, technological demonstrations were conducted in participatory mode to evaluate the impact of improved cultivar with balanced use of nutrients especially potassium and sulphur on productivity, profitability and to identify the yield gaps of mustard and linseed in Kymore Plateau and Satpura hills zone of Central India.

\section{Materials and Methods}

Frontline demonstrations were conducted in participatory mode during to 2007-08 to 2009-10 on linseed and 2010-11 to 2011-12 on mustard to evaluate the effect of technology package in rice-linseed and ricemustard cropping system at 33 and 25 farmers' fields located in four villages spread over three blocks of Katni district (Table 1) falls under Kymore Plateau and Satpura Hills zone of Central India. The upland mixed red to shallow black soils of the demonstration sites was generally silty clay loam in texture. Soils were very low to low in available N, medium in available $\mathrm{P}$ and $\mathrm{K}$, and low in available sulphur. Each demonstration was conducted in an area of 0.40 ha with a check plot closest to the demonstration site was kept as farmers' practice. The improved production technology package included multiple disease (rust, wilt and powdery 
mildew) resistant varieties of linseed, JLS 9 in 2007-08 to 2008-09 and JLS 23 in 2009-10 in the demonstrations.

In the mustard demonstrations, early and aphid tolerant variety 'Pusa Mahak' was used during 2010-11 and 2011-12. Seed treatment was carried out with the contact and systemic fungicides viz. thiram @ $2 \mathrm{~g}$ and carbendazim @ $1 \mathrm{~g} \mathrm{~kg}^{-1}$ seed and subsequently inoculated with azotobactor and phosphate solubilizing bacteria (PSB) @ $10 \mathrm{~g} \mathrm{~kg}^{-1}$ seed for increasing the availability of nitrogen to the crop and better phosphorus use efficiency. All the demonstrations on linseed and mustard were laid in II $^{\text {nd }}$ fortnight of October every year using the seed rate of 25 and $5 \mathrm{~kg} \mathrm{ha}^{-1}$ respectively. The distance between the rows was kept 30 and $45 \mathrm{~cm}$ and within a row 7 and $10 \mathrm{~cm}$ spacing maintained between the plants in linseed and mustard respectively. The NPK and sulphur applied @ 60:40:20:40 $\mathrm{kg} \mathrm{ha}{ }^{-1}$ on the basis of soil test values. Fertilizer sources included urea $(46 \% \mathrm{~N})$, single super phosphate $\left(16 \% \mathrm{P}_{2} \mathrm{O}_{5}\right.$ and $12 \%$ $\mathrm{S})$ and potassium chloride $\left(60 \% \mathrm{~K}_{2} \mathrm{O}\right)$. Entire quantities of $\mathrm{P}, \mathrm{K}$ and $\mathrm{S}$ and half of the total $\mathrm{N}$ were applied during sowing. The remaining $\mathrm{N}$ was top-dressed at pre-flowering stage. Preemergence herbicide i.e. pendimethaline was sprayed through flat fan nozzle sprayer @ 1kg a.i. ha ${ }^{-1}$ after sowing for efficient weed management. Both the crops were harvested at maturity stage during last week of February to $\mathrm{I}^{\text {st }}$ week of March every year.

Yield attributes i.e. number of primary branches plant $^{-1}$, number of capsules plant ${ }^{-1}$, number of seeds capsule ${ }^{-1}$; number of siliqua plant $^{-1}$ number of seeds siliqua ${ }^{-1}$ (in mustard) and seed yield was recorded in each crop during the study. Economic comparisons for each year included analysis of net returns, as well as the additional returns, incremental $\mathrm{B}: \mathrm{C}$ ratio in each individual location and mean over the locations. Yield gaps and technology index was also analyzed to assess the feasibility of the technological demonstrations. Results reported here are year wise averages of the locations and average of three and two years of study in linseed and mustard respectively.

The feasibility of technology in the demonstrations was workout through technology gap, extension gap and technology index. Technology index thus indicates the feasibility of the evolved technology. To assess the technology gap, extension gap and technology index, following formulae given by Kadian et al., (1997) was used:

Technology Gap $=$ Potential Yield -
Demonstration Yield
Extension gap $=$ Demonstration yield -
farmers yield
Technology Index $=(\mathrm{P}-\mathrm{D} / \mathrm{P}) \times 100$
Where, $\mathrm{P}=$ Potential yield, $\mathrm{D}=$ Demonstration
yield

\section{Results and Discussion}

The data presented in Table 2 dealt with effect of potassium and sulphur on yield attributes such as number of branches plant ${ }^{-1}$, number of capsules plant ${ }^{-1}$ and number of seeds capsule ${ }^{-1}$ in linseed recorded in each season during 2007-08 to 2009-10. The number of primary branches plant ${ }^{-1}$ were in range of 2.6 to 2.8 with the average of 2.7 in technological demonstrations and 2.4 to 2.6 with an average of 2.5 in farmers' practice during the study period. An increase of 6.58 percent was noticed in mean number of primary branches plant $^{-1}$ under improved technology than that of farmers' practice over the years. The number of capsules plant ${ }^{-1}$ ranged from 126.6 to 141.5 in improved technology demonstrations and 104.9 to 109.8 in farmers' practice during 2007-08 to 200910. The average number of capsules plant ${ }^{-1}$ was recorded 134.97 in improved technology 
demonstrations with an increase of 25.78 percent over farmers' practice (107.30) during the demonstration period. The number of seeds capsule ${ }^{-1}$ in technological demonstrations were recorded to be $6.92,6.96$ and 6.88, however, 6.54, 6.69 and 6.62 in farmers' practice during 2007-08 to 2009-10 respectively. The mean value of seeds capsule $^{-1}$ over the years was 6.92 in improved practice with an increase of 4.58 percent over farmers' practice (6.62).

The data given in Table 3 dealt with effect of potassium and sulphur on yield attributes such as number of branches plant ${ }^{-1}$, number of siliqua plant ${ }^{-1}$ and number of seeds siliqua ${ }^{-1}$ in mustard studied in each season during 2010 11 to 2011-12. The number of primary branches plant ${ }^{-1}$ ranged from 8.2 to 8.6 with the average of 8.4 in technological demonstrations and 5.6 to 6 with an average of 5.8 in farmers' practice during the study period. An increase of 44.83 percent was noticed in mean number of primary branches plant $^{-1}$ under improved technology than that of farmers' practice over the years. The number of siliqua plant ${ }^{-1}$ were in range of 121.26 to 134.75 with the average of 128 in technology demonstrations and 84.16 to 97.38 in farmers' practice with the average of 91.76 during 2010-11 and 2011-12. An increase of 39.49 percent was noticed in mean number of siliqua plant $^{-1}$ under improved practice than that of farmers' practice over a year. The number of seeds siliqua $^{-1}$ in technological demonstrations was recorded to be 9.34 and 11.51, however, 6.93 and 8.67 in farmers' practice during 2010-11 and 2011-12 respectively. The mean value of seeds siliqua ${ }^{1}$ over a year was 10.43 in improved practice with an increase of 33.72 percent over farmers' practice (7.80).

Use of improved cultivar and balanced use of nutrients especially potassium and sulphur which might be attributed to increase in growth characters i.e. branches plant $^{-1}$, Number of siliqua plant ${ }^{-1}$ and Number of seeds siliqua ${ }^{-1}$ of mustard under the technological demonstrations. It was observed by the researchers in their research findings that plant height, branches per plant, number of siliquae per plant and siliqua length of mustard increased with addition of sulphur @ 15 and $20 \mathrm{~kg} \mathrm{ha}^{-1}$ over the control (Rakesh and Bainik, 2016; Solanki and Sharma 2016).

The data pertaining to response of potassium and sulphur on test weight (g 1000 seed $^{-1}$ ), seed yield $\left(\mathrm{kg} \mathrm{ha}^{-1}\right)$ in improved technology, farmers' practice and additional yield in technological demonstrations of linseed given in Table 4. It is apparent from the table that the test weight was in range of 7.13 to $7.21 \mathrm{~g}$ 1000 seed $^{-1}$ in improved technology during 2007-08 to 2009-10 with the mean value of $7.17 \mathrm{~g} 1000 \mathrm{seed}^{-1}$ which was 4.98 percent higher to that of farmers' practice $(6.83 \mathrm{~g}$ 1000 seed $\left.^{-1}\right)$. The test weight in farmers'

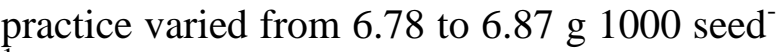
1 during the study period. Linseed productivity under technological demonstrations, laid in Kymore plateau and Satpura hills zone, was recorded 906 to 1147 $\mathrm{kg} \mathrm{ha}^{-1}$ during 2007-08 to 2009-10 with the mean yield of $1035.67 \mathrm{~kg} \mathrm{ha}^{-1}$. The average seed yield under farmers' practice (local check) was recorded to be 721,615 and 528 $\mathrm{kg} \mathrm{ha}^{-1}$ with the mean yield of $621.33 \mathrm{~kg} \mathrm{ha}^{-1}$ in respective crop seasons of 2007-08, 200809 and 2009-10. The additional yield under technological demonstrations over farmers practice was estimated between 378 to $439 \mathrm{~kg}$ $\mathrm{ha}^{-1}$ during 2007-08 to 2009-10 with a mean value of $414.33 \mathrm{~kg} \mathrm{ha}^{-1}$. It was observed from the data that under the technological demonstrations an enhanced productivity of 59.08, 71.38 and 71.59 percent found in 200708 to $2009-10$ respectively with the mean value of 66.68 percent to that of local check (farmers' practice). 
The yield enhancement under the technological demonstrations was possibly due to use of multiple disease resistant variety, balanced use of nutrients especially potassium and sulphur which might be attributed to growth and yield of linseed. Sulphur application has been reported to favor yield due to proper partitioning of photo syntheses from source to sink (Singh et. al, 2006). These results corroborated the findings of Dubey et al., (2000), Banerjee (2001), Sune et al., (2006) and Singh and Singh (2007).

Effect of potassium and sulphur on test weight (g 1000 seed $\left.^{-1}\right)$, seed yield $\left(\mathrm{kg} \mathrm{ha}^{-1}\right)$ in improved technology, farmers' practice and additional yield in technological demonstrations of mustard given in Table 5. It is evident from the table that the test weight

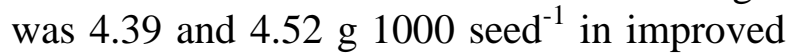
technology during 2010-11 and 2011-12 with

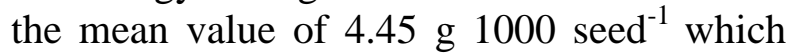
was 48.33 percent higher to that of farmers' practice $\left(3 \mathrm{~g} 1000 \mathrm{seed}^{-1}\right)$. The test weight in farmers' practice was noted to be 3.02 and

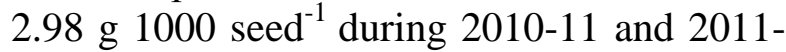
12. The productivity of mustard under technological demonstrations was 1164 and $1210 \mathrm{~kg} \mathrm{ha}^{-1}$ during 2010-11 and 2011-12 with the mean yield of $1187 \mathrm{~kg} \mathrm{ha}^{-1}$. The average seed yield under farmers' practice was observed to be 625 and $650 \mathrm{~kg} \mathrm{ha}^{-1}$ with the mean yield of $637.50 \mathrm{~kg} \mathrm{ha}^{-1}$ in the respective crop seasons during 2010-11 and 2011-12. The additional yield under technological demonstrations over farmers practice was found 539 and $560 \mathrm{~kg} \mathrm{ha}^{-1}$ in 2010-11 to 2011-12 with a mean value of $549.50 \mathrm{~kg} \mathrm{ha}^{-1}$. It was empirical from the data that under the technological demonstrations an enhanced productivity of 86.24 and 86.15 percent found in 2010-11 and 2011-12 respectively with the mean value of 86.20 percent to that of local check (farmers' practice).
The weight of 1000 seed and grain yield increased with the positive effect of potassium and sulphur application. Similar results were also noted by Singh and Singh (1995) with the application of $50 \mathrm{~kg} \mathrm{~K}_{2} \mathrm{O}$ and $40 \mathrm{~kg} \mathrm{~S} \mathrm{ha}{ }^{-1}$ in soybean. With increasing supply of sulphur the process of tissue differentiation from somatic to reproductive, meristematic activity and development of floral primordial might have increased, resulting in more flowers and siliqua, longer siliqua and higher seed yield. Chakraborty and Das (2000) reported that S and B application significantly influenced the dry matter and seed yield of mustard. Kumar and Trivedi (2011) and Singh et al., (2015) also reported an increase in seed yield of mustard with the application of S levels.

The data presented in Table 6 dealt with the cultivation costs in improved and farmers' practices, net returns and benefit cost ratio of linseed. The economics of linseed cultivation and its practicability in technological demonstrations was measured considering the existing prices of inputs and production costs over farmers' traditional practices. The cost of production under improved practice varied from Rs 6749 to 7899 ha $^{-1}$ during 2007-08 to 2009-10 with an average cost of Rs $7466 \mathrm{ha}^{-1}$ in comparison to that of Rs 5200 to $6350 \mathrm{ha}^{-1}$ with an average production cost of Rs $5966.67 \mathrm{ha}^{-1}$ under local check (farmers' practice). An additional cultivation cost of Rs 1400 to $1549 \mathrm{ha}^{-1}$ incurred in the improved practice with an average additional production cost of Rs 1499.33 ha $^{-1}$ over farmers' practice (local check). The additional cost incurred in the improved practices was chiefly due to additional cost involved in fertilizers for balanced nutrient application and use of herbicide for weed management. The net return in linseed cultivation was found to be remarkably higher under technology demonstrations which varied from Rs 19430 to $24220 \mathrm{ha}^{-1}$ with the mean value of Rs 
$22457 \mathrm{ha}^{-1}$ than that of farmers' practice where it ranged from Rs 7906 to $14267 \mathrm{ha}^{-1}$ with the average of Rs $11424.33 \mathrm{ha}^{-1}$. An additional net return of Rs 9953, 11621 and 11524 was found under the technological demonstrations in the respective years from 2007-08 to 2009-10 with an average net return of Rs $11032.67 \mathrm{ha}^{-1}$ over farmers' practice. The technology demonstrations also resulted in higher benefit cost ratio during the study period and the values noted to be 4.58 , 4 and 3.51 next to the farmers' practice where it was noted to be 3.74, 2.91 and 2.25 from 2007-08 to 2009-10 respectively. An incremental $\mathrm{BC}$ ratio of $0.84,1.09$ and 1.26 recorded in improved practice during the demonstration period since 2007-08 to 200910 with the average BCR of 1.06. The results of the study clearly indicate the feasibility and efficiency of the technological demonstrations conducted during the three consecutive years.

The data given in Table 7 deal with the cultivation costs in improved and farmers' practices, net returns and benefit cost ratio of mustard. The economics of mustard farming and its viability in technological demonstrations was measured considering the existing prices of inputs and production costs over farmers' conventional practices. The cost of production under improved practice was Rs $7650 \mathrm{ha}^{-1}$ during 2010-11 and 2011-12 in comparison to that of Rs $6150 \mathrm{ha}^{-1}$ under local check (farmers' practice). An additional cultivation cost of Rs $1500 \mathrm{ha}^{-1}$ incurred in the improved practice over farmers' practice (local check).

The additional cost incurred in the improved practices was primarily due to additional cost involved in fertilizers for balanced nutrient application and use of herbicide for weed management. The net return in mustard cultivation was found to be remarkably higher under the improved practice which was noted to be Rs 26942 and 26230 ha $^{-1}$ with the mean value of Rs $25586 \mathrm{ha}^{-1}$ over farmers' practice where it was Rs 11350 and 12050 ha $^{-1}$ with the average of Rs $11700 \mathrm{ha}^{-1}$ in 2010-11 and 2011-12 respectively. An additional net return of Rs 13592 and 14180 was found under the technological demonstrations in 2010-11 and 2011-12 with an average net return of Rs $13886 \mathrm{ha}^{-1}$ over farmers' practice. The technology demonstrations also resulted in higher benefit cost ratio during the study period and the values were 4.26 and 4.43 over farmers' practice in which it was 2.84 and 2.96 in 2010-11 and 2011-12 respectively. An incremental $\mathrm{BC}$ ratio of 1.42 and 1.47 recorded under technology demonstrations 2010-11 and 2011-12 respectively with the average BCR of 1.45 . The results of the study undoubtedly indicate the practicability and effectiveness of the technological demonstrations conducted during the two consecutive years.

The data presented in Table 8 , shows the technology gap, extension gap and technology index of the technological demonstrations conducted on linseed during 2007-08 to 200910 in three consecutive crops. The technology gap in the demonstrations using JLS 9 and JLS 23 cultivar was found as 153, 246 and 94 $\mathrm{kg} \mathrm{ha}^{-1}$ respectively during 2007-08, 2008-09 and $2009-10$ with the mean value of 114.33 $\mathrm{kg} \mathrm{ha}{ }^{-1}$ which was close to the cultivars' potential, clearly indicates that the technology packages used involving above cultivars are feasible in the region. Similarly the technology index in the above cultivars was estimated to be 11.77 and 18.92 (JLS 9) in 2007-08 and 2008-09; and 9.4 percent (JLS 23 ) in 2009-10 with the mean value of 9.94 percent which was also close to the both cultivars' potential, indicated the practicability of evolved technology. The extension gap in the demonstrations using $\mathrm{cv}$. JLS 9 was 426 and $439 \mathrm{~kg} \mathrm{ha}^{-1}$ in 2007-08 and 2008-09 respectively; and $378 \mathrm{~kg} \mathrm{ha}^{-1}$ in 2009-10 with the mean value of 414.33 
$\mathrm{kg} \mathrm{ha}^{-1}$ which reflected a notable yield gap which can be minimized by disseminating adequately the technological packages in the region and up scaling the adoption percentage to increase the crop production and productivity. There are still ample possibilities to minimize the above yield gaps to enhance the crop productivity in the zone. The data given in Table 9 reveals the technology gap, extension gap and technology index of the technological demonstrations conducted on mustard during 2010-11 and 2011-12. The technology gap in the demonstrations using Pusa Mahak cultivar was noted to be 586 and $540 \mathrm{~kg} \mathrm{ha}^{-1}$ respectively during 2010-11 and 2011-12 which indicates that the technology packages used involving above cultivar is viable in the region.

Table.1 Details of technological interventions under demonstrations and farmers' practices

\begin{tabular}{|c|c|c|c|c|c|c|c|c|}
\hline \multirow[t]{2}{*}{ Year } & \multirow[t]{2}{*}{$\begin{array}{l}\text { Area } \\
\text { (ha) }\end{array}$} & \multirow{2}{*}{\begin{tabular}{|c|}
$\begin{array}{c}\text { No. of } \\
\text { demonst } \\
\text { rations }\end{array}$ \\
\end{tabular}} & \multicolumn{2}{|c|}{ Location } & \multicolumn{2}{|c|}{ Variety used } & \multicolumn{2}{|c|}{$\begin{array}{c}\text { Nutrients applied } \\
\left(\mathrm{kg} \mathrm{ha}^{-1}\right)\end{array}$} \\
\hline & & & Village & Block & $\begin{array}{l}\text { Improved } \\
\text { practice }\end{array}$ & $\begin{array}{l}\text { Farmers' } \\
\text { Practice }\end{array}$ & $\begin{array}{l}\text { Improved } \\
\text { practice }\end{array}$ & $\begin{array}{l}\text { Farmers' } \\
\text { Practice }\end{array}$ \\
\hline \multicolumn{9}{|l|}{ Linseed } \\
\hline 2007-08 & 6.0 & 13 & Padaria & Katni & JLS 9 & Local & $\mathrm{N}_{60} \mathrm{P}_{40} \mathrm{~K}_{20} \mathrm{~S}_{40}$ & $\mathrm{~N}_{32} \mathrm{P}_{34} \mathrm{~K}_{0} \mathrm{~S}_{0}$ \\
\hline 2008-09 & 5.0 & 12 & Padaria & Katni & JLS 9 & Local & $\mathrm{N}_{60} \mathrm{P}_{40} \mathrm{~K}_{20} \mathrm{~S}_{40}$ & $\mathrm{~N}_{32} \mathrm{P}_{34} \mathrm{~K}_{0} \mathrm{~S}_{0}$ \\
\hline \multirow[t]{2}{*}{ 2009-10 } & \multirow[t]{2}{*}{3.2} & \multirow[t]{2}{*}{08} & Banda & Katni & \multirow[t]{2}{*}{ JL 23} & \multirow[t]{2}{*}{ Local } & \multirow[t]{2}{*}{$\mathrm{N}_{60} \mathrm{P}_{40} \mathrm{~K}_{20} \mathrm{~S}_{40}$} & \multirow[t]{2}{*}{$\mathrm{N}_{32} \mathrm{P}_{34} \mathrm{~K}_{0} \mathrm{~S}_{0}$} \\
\hline & & & Padwar & Bahoriband & & & & \\
\hline Total & 14.2 & 33 & - & - & - & - & - & - \\
\hline Average & 4.73 & 11 & - & - & - & - & $\mathrm{N}_{60} \mathrm{P}_{40} \mathrm{~K}_{20} \mathrm{~S}_{40}$ & $\mathrm{~N}_{32} \mathrm{P}_{34} \mathrm{~K}_{0} \mathrm{~S}_{0}$ \\
\hline \multicolumn{9}{|l|}{ Mustard } \\
\hline 2010-11 & 5.0 & 12 & Banda & Katni & $\begin{array}{l}\text { Pusa } \\
\text { Mahak }\end{array}$ & $\begin{array}{l}\text { Local } \\
\text { 'lahi' }\end{array}$ & $\mathrm{N}_{60} \mathrm{P}_{40} \mathrm{~K}_{20} \mathrm{~S}_{40}$ & $\mathrm{~N}_{32} \mathrm{P}_{34} \mathrm{~K}_{0} \mathrm{~S}_{0}$ \\
\hline 2011-12 & 5.2 & 13 & $\begin{array}{l}\text { Banda } \\
\text { Imaliya }\end{array}$ & $\begin{array}{c}\text { Katni } \\
\text { Dhimarkhera }\end{array}$ & $\begin{array}{c}\text { Pusa } \\
\text { Mahak }\end{array}$ & $\begin{array}{l}\text { Local } \\
\text { 'lahi' }\end{array}$ & $\mathrm{N}_{60} \mathrm{P}_{40} \mathrm{~K}_{20} \mathrm{~S}_{40}$ & $\mathrm{~N}_{32} \mathrm{P}_{34} \mathrm{~K}_{0} \mathrm{~S}_{0}$ \\
\hline Total & 10.2 & 25 & - & - & - & - & - & - \\
\hline Average & 5.1 & 12.5 & - & - & - & - & $\mathrm{N}_{60} \mathrm{P}_{40} \mathrm{~K}_{20} \mathrm{~S}_{40}$ & $\mathrm{~N}_{32} \mathrm{P}_{34} \mathrm{~K}_{0} \mathrm{~S}_{0}$ \\
\hline
\end{tabular}

Table.2 Effect of potassium and sulphur on yield attributes of linseed

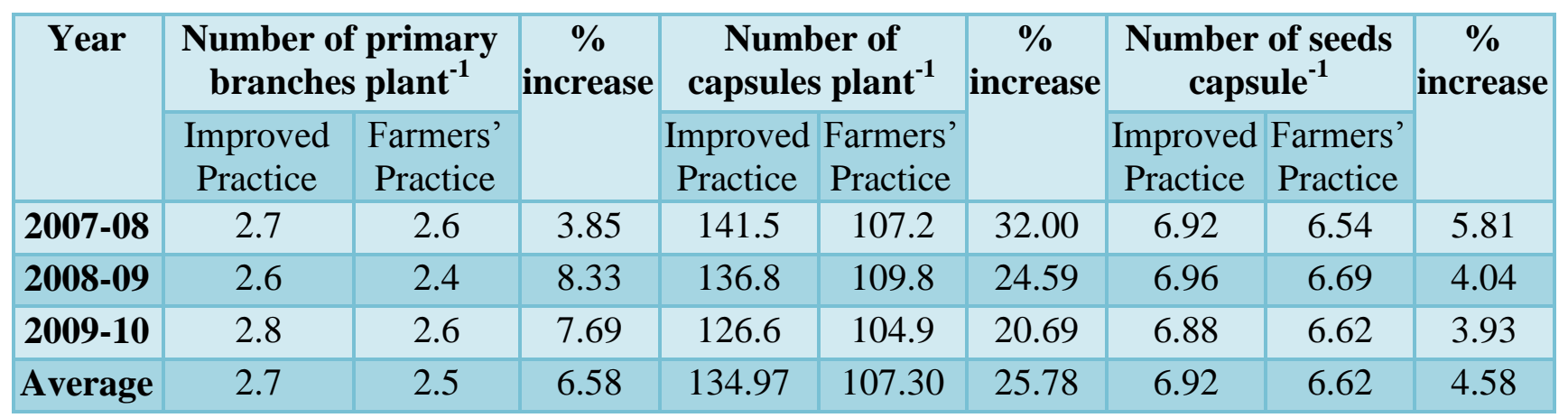


Table.3 Effect of potassium and sulphur on yield attributes of mustard

\begin{tabular}{|c|c|c|c|c|c|c|c|c|c|}
\hline \multirow[t]{2}{*}{ Year } & \multicolumn{2}{|c|}{$\begin{array}{c}\text { Number of } \\
\text { primary branches } \\
\text { plant }^{-1}\end{array}$} & \multirow[t]{2}{*}{$\begin{array}{c}\% \\
\text { increase }\end{array}$} & \multicolumn{2}{|c|}{$\begin{array}{c}\text { Number of siliqua } \\
\text { plant }^{-1}\end{array}$} & \multirow[t]{2}{*}{$\begin{array}{c}\% \\
\text { increase }\end{array}$} & \multicolumn{2}{|c|}{\begin{tabular}{|c|} 
Number of seeds \\
siliqua $^{-1}$
\end{tabular}} & \multirow[t]{2}{*}{$\begin{array}{c}\% \\
\text { increase }\end{array}$} \\
\hline & $\begin{array}{l}\text { Improved } \\
\text { Practice }\end{array}$ & $\begin{array}{l}\text { Farmers' } \\
\text { Practice }\end{array}$ & & $\begin{array}{l}\text { Improved } \\
\text { Practice }\end{array}$ & $\begin{array}{l}\text { Farmers' } \\
\text { Practice }\end{array}$ & & $\begin{array}{l}\text { Improved } \\
\text { Practice }\end{array}$ & $\begin{array}{c}\text { Farmers' } \\
\text { Practice }\end{array}$ & \\
\hline 2010-11 & 8.6 & 5.6 & 53.57 & 121.26 & 84.16 & 44.08 & 9.34 & 6.93 & 34.78 \\
\hline 2011-12 & 8.2 & 6.0 & 36.67 & 134.75 & 97.38 & 38.38 & 11.51 & 8.67 & 32.76 \\
\hline Average & 8.4 & 5.8 & 44.83 & 128.00 & 91.76 & 39.49 & 10.43 & 7.80 & 33.72 \\
\hline
\end{tabular}

Table.4 Effect of potassium and sulphur on test weight and seed yield of linseed

\begin{tabular}{|c|c|c|c|c|c|c|c|}
\hline \multirow[t]{2}{*}{ Year } & \multicolumn{2}{|c|}{$\begin{array}{c}\text { Test weight } \\
\left(\mathrm{g} 1000 \text { seed }^{-1}\right)\end{array}$} & \multirow[t]{2}{*}{$\begin{array}{c}\% \\
\text { increase }\end{array}$} & \multicolumn{2}{|c|}{$\begin{array}{l}\text { Average seed yield } \\
\left(\mathrm{kg} \mathrm{ha}^{-1}\right)\end{array}$} & \multirow{2}{*}{$\begin{array}{c}\text { Additional } \\
\text { yield over FP } \\
\left(\mathrm{kg} \mathrm{ha}^{-1}\right)\end{array}$} & \multirow[t]{2}{*}{$\begin{array}{c}\% \\
\text { increase }\end{array}$} \\
\hline & $\begin{array}{l}\text { Improved } \\
\text { Practice }\end{array}$ & $\begin{array}{l}\text { Farmers' } \\
\text { Practice }\end{array}$ & & $\begin{array}{l}\text { Improved } \\
\text { Practice }\end{array}$ & $\begin{array}{l}\text { Farmers' } \\
\text { Practice }\end{array}$ & & \\
\hline 2007-08 & 7.13 & 6.83 & 4.39 & 1147 & 721 & 426 & 59.08 \\
\hline 2008-09 & 7.18 & 6.87 & 4.51 & 1054 & 615 & 439 & 71.38 \\
\hline 2009-10 & 7.21 & 6.78 & 6.34 & 906 & 528 & 378 & 71.59 \\
\hline Average & 7.17 & 6.83 & 4.98 & 1035.67 & 621.33 & 414.33 & 66.68 \\
\hline
\end{tabular}

Table.5 Effect of potassium and sulphur on test weight and seed yield of mustard

\begin{tabular}{|c|c|c|c|c|c|c|c|}
\hline \multirow[t]{2}{*}{ Year } & \multicolumn{2}{|c|}{$\begin{array}{c}\text { Test weight } \\
\left(\mathrm{g} 1000 \text { seed }^{-1}\right)\end{array}$} & \multirow[t]{2}{*}{$\begin{array}{c}\% \\
\text { increase }\end{array}$} & \multicolumn{2}{|c|}{$\begin{array}{l}\text { Average seed yield } \\
\left(\mathrm{kg} \mathrm{ha}^{-1}\right)\end{array}$} & \multirow{2}{*}{$\begin{array}{c}\text { Additional } \\
\text { yield over FP } \\
{\left(\mathrm{kg} \mathrm{ha}^{-1}\right)}^{2}\end{array}$} & \multirow[t]{2}{*}{$\begin{array}{c}\% \\
\text { increase }\end{array}$} \\
\hline & $\begin{array}{l}\text { Improved } \\
\text { Practice }\end{array}$ & $\begin{array}{c}\text { Farmers' } \\
\text { Practice }\end{array}$ & & $\begin{array}{l}\text { Improved } \\
\text { Practice }\end{array}$ & $\begin{array}{l}\text { Farmers' } \\
\text { Practice }\end{array}$ & & \\
\hline 2010-11 & 4.39 & 3.02 & 45.36 & 1164 & 625 & 539 & 86.24 \\
\hline 2011-12 & 4.52 & 2.98 & 51.68 & 1210 & 650 & 560 & 86.15 \\
\hline Average & 4.45 & 3.00 & 48.33 & 1187 & 637.50 & 549.50 & 86.20 \\
\hline
\end{tabular}

Table.6 Economics of linseed cultivation in improved and farmers' practices

\begin{tabular}{|c|c|c|c|c|c|c|c|c|c|}
\hline \multirow[t]{2}{*}{ Year } & \multicolumn{2}{|c|}{$\begin{array}{l}\text { Average cost of } \\
\text { cultivation } \\
\left(\mathrm{Rs} \mathrm{ha}^{-1}\right)\end{array}$} & \multirow{2}{*}{$\begin{array}{l}\text { Addition } \\
\text { al cost } \\
\text { over FP } \\
\left(\mathrm{Rs} \mathrm{ha}^{-1}\right)\end{array}$} & \multicolumn{2}{|c|}{$\begin{array}{l}\text { Average net } \\
\text { returns } \\
\left(\text { Rs ha }^{-1}\right)\end{array}$} & \multirow[t]{2}{*}{$\begin{array}{l}\text { Additional } \\
\text { return over } \\
\text { FP }\left(\text { Rs ha }^{-1}\right)\end{array}$} & \multicolumn{2}{|c|}{ B:C ratio } & \multirow[t]{2}{*}{$\begin{array}{c}\text { Incrementa } \\
\text { I BCR over } \\
\text { FP }\end{array}$} \\
\hline & IP & FP & & IP & FP & & IP & FP & \\
\hline 2007-08 & 674 & 520 & 1549 & 2422 & 14267 & & 4.58 & 3.74 & \\
\hline 2008-09 & 7899 & 6350 & 15 & 23721 & 12100 & 11621 & 4.00 & 2.91 & 1.09 \\
\hline 2009-10 & 7750 & 6350 & 1400 & 19430 & 7906 & 11524 & 3.51 & 2.25 & 1.26 \\
\hline Average & 7466 & 5966.67 & 1499.33 & 22457 & 11424.33 & 11032.67 & 4.03 & 2.97 & 1.06 \\
\hline
\end{tabular}


Table.7 Economics of mustard cultivation in improved and farmers' practices

\begin{tabular}{|c|c|c|c|c|c|c|c|c|c|}
\hline \multirow[t]{2}{*}{ Year } & \multicolumn{2}{|c|}{$\begin{array}{l}\text { Average cost of } \\
\text { cultivation } \\
\left(\operatorname{Rs~ha}^{-1}\right)\end{array}$} & \multirow{2}{*}{$\begin{array}{l}\text { Additional } \\
\text { cost over } \\
\text { FP } \\
\left(\mathrm{Rs} \mathrm{ha}^{-1}\right)\end{array}$} & \multicolumn{2}{|c|}{$\begin{array}{l}\text { Average net } \\
\text { returns } \\
\left(\mathrm{Rs} \mathrm{ha}^{-1}\right)\end{array}$} & \multirow[t]{2}{*}{$\begin{array}{l}\text { Additional } \\
\text { return over } \\
\text { FP }\left(\operatorname{Rs~ha}{ }^{-1}\right)\end{array}$} & \multicolumn{2}{|c|}{ B:C ratio } & \multirow[t]{2}{*}{$\begin{array}{c}\text { Incrementa } \\
\text { I BCR over } \\
\text { FP }\end{array}$} \\
\hline & IP & FP & & IP & FP & & IP & FP & \\
\hline 2010-11 & 7650 & 6150 & 1500 & 24942 & 11350 & 13592 & 4.26 & 2.84 & 1.42 \\
\hline 2011-12 & 7650 & 6150 & 1500 & 26230 & 12050 & 14180 & 4.43 & 2.96 & 1.47 \\
\hline Average & 7650 & 6150 & 1500 & 25586 & 11700 & 13886 & 4.35 & 2.9 & 1.45 \\
\hline
\end{tabular}

Table.8 Yield gaps and technology index in linseed under technological demonstrations and farmers' practices

\begin{tabular}{|c|c|c|c|c|c|c|c|}
\hline \multirow[t]{2}{*}{ Year } & \multirow[t]{2}{*}{ Variety } & \multirow{2}{*}{$\begin{array}{c}\text { Potential } \\
\text { yield } \\
\left(\mathrm{kg} \mathrm{ha}^{-1}\right)\end{array}$} & \multicolumn{2}{|c|}{ Average yield (kg ha $\left.{ }^{-1}\right)$} & \multirow{2}{*}{$\begin{array}{l}\text { Technology } \\
\text { gap } \\
\left(\mathrm{kg} \mathrm{ha}^{-1}\right)\end{array}$} & \multirow{2}{*}{$\begin{array}{c}\text { Extension } \\
\text { gap } \\
\left(\mathrm{kg} \mathrm{ha}^{-1}\right)\end{array}$} & \multirow{2}{*}{$\begin{array}{l}\text { Technology } \\
\text { Index }\end{array}$} \\
\hline & & & $\begin{array}{l}\text { Improved } \\
\text { practice }\end{array}$ & $\begin{array}{l}\text { Farmers' } \\
\text { practice }\end{array}$ & & & \\
\hline 2007-08 & JLS 9 & 1300 & 1147 & 721 & 153 & 426 & 11.77 \\
\hline 2008-09 & JLS 9 & 1300 & 1054 & 615 & 246 & 439 & 18.92 \\
\hline 2009-10 & JLS 23 & 1000 & 906 & 528 & 94 & 378 & 9.4 \\
\hline Average & - & 1150 & 1035.67 & 621.33 & 114.33 & 414.33 & 9.94 \\
\hline
\end{tabular}

Table.9 Yield gaps and technology index in mustard under technological demonstrations and farmers' practices

\begin{tabular}{|c|c|c|c|c|c|c|c|}
\hline \multirow[t]{2}{*}{ Year } & \multirow[t]{2}{*}{ Variety } & \multirow{2}{*}{$\begin{array}{c}\text { Potentia } \\
\text { l yield } \\
\left(\mathrm{kg} \mathrm{ha}^{-1}\right)\end{array}$} & \multicolumn{2}{|c|}{ Average yield $\left(\mathrm{kg} \mathrm{ha}^{-1}\right)$} & \multirow{2}{*}{$\begin{array}{c}\text { Technology } \\
\text { gap } \\
\left(\mathrm{kg} \mathrm{ha}^{-1}\right)\end{array}$} & \multicolumn{2}{|c|}{ Extension Technology } \\
\hline & & & $\begin{array}{l}\text { Improved } \\
\text { practice }\end{array}$ & $\begin{array}{l}\text { Farmers' } \\
\text { practice }\end{array}$ & & $\underset{\left(\mathrm{kg} \mathrm{ha}^{-1}\right)}{\text { gap }}$ & Index \\
\hline 2010-11 & Pusa Mahak & 1750 & 1164 & 625 & 586 & 539 & 33.49 \\
\hline 2011-12 & Pusa Mahak & 1750 & 1210 & 650 & 540 & 560 & 30.86 \\
\hline Average & - & 1750 & 1187 & 637.50 & 563 & 549.50 & 32.17 \\
\hline
\end{tabular}

Similarly the technology index in the above cultivar was observed to be 33.49 and 30.86 percent in 2010-11 and 2011-12 indicated the significance of evolved technology. The technology gap calculated as a whole in two crop seasons show that an average of $563 \mathrm{~kg}$ ha $^{-1}$ yield gap with 32.17 percent technology index was evident in the demonstrations conducted on farmers' fields which may perhaps emerged due to various climatic and soil factors. There are ample possibilities to minimize the above gap to enhance the crop productivity in the zone. The extension gap in the demonstrations was 539 and $560 \mathrm{~kg} \mathrm{ha}^{-1}$ respectively in 2010-11 and 2011-12 with the mean value of $549.50 \mathrm{~kg} \mathrm{ha}^{-1}$, reflected a remarkable yield gap which can be minimized by disseminating adequately the technological packages in the region and up-scaling the adoption percentage to increase the crop production and productivity.

Based on the results obtained from the study conducted on rabi oilseeds (linseed and 
mustard) it may be concluded that use of improved cultivar and balance application of nutrients especially potassium and sulphur are required to be adopted to get the optimum crop productivity. Delayed sowing; imbalanced fertilizer application; inappropriate weed management practices and unsuitable plant protection measures may fundamentally lower the seed yield of linseed and mustard.

The demonstrated technology is also feasible to combat with adverse climatic conditions and getting optimum grain yields. The findings of the technological demonstrations observed to be effectual and economically feasible in the region as these resulted higher net returns and minimized the technology gap and index during the study.

\section{References}

Ag. Statistics (2017). Directorate of Economics and Statistics, Department of Agriculture Cooperation and Farmers Welfare, Ministry of Agriculture \& Farmers Welfare, Government of India, New Delhi.

Banerjee, S., Basu, T.K., Bhowamick, N. and Bhattacharya, J. (2001). Effect of potassium and sulphur on growth attributes, yield parameters and seed yield of linseed (Linum usitatissimum, L.). Journal of Interacademica, 5(3): 318-323.

Chakraborty, A.K. and Das, D.K. (2000). Interaction between $B$ and $S$ on different quality parameters of rape $(B$. compastris). Research on Crops, 1: 326-329.

DRMR (2011). VISION 2030. Directorate of Rapeseed-Mustard Research, Bharatpur Rajasthan. pp30.

Dubey, S.D., Hussain, K. and Srivastava, R.L. (2000). Response of phosphorus and sulphur in linseed (Linum usitatissimum, L.). Advances in Plant Sciences, 13(2): 535-538.

GoI (2018). Annual Report 2017-18. Department of Agriculture, Cooperation \& Farmers Welfare, Ministry of Agriculture \& Farmers Welfare, Government of India, New Delhi.

Hegde, D.M. (2009). Can India achieve selfreliance in oilseeds? In: Souvenir: National symposium on Vegetable Oils Scenario: Approaches to meet the growing demands. January 29-31, P (1-15).

Kadian, K.S., Sharma, R. and Sharma, A.K. (1997). Evaluation of Frontline demonstration trials on oilseeds in Kangra Vally of Himachal Pradesh. Ann. Agri. Res., 18: 40.

Kumar, R. and Trivedi, S.K. (2011). Effect of levels and sources of sulphur on yield, quality and nutrient uptake by mustard (Brassica juncea L). Progressive Agriculture, 11(1): 58-61.

Rakesh, S. and Banik, G.C. (2016). Effect of sulphur levels and sources on growth, yield and quality of mustard in Terai region of West Bengal. Annals of Plant and Soil Research, 18(2): 152-155.

Rathore, S.S., Shekhawat, K., Kandpal, B.K., Premi, O.P., Singh, S.P., Singh, G.C. and Singh, D. (2015). Sulphur management for increased productivity of indian mustard: A review. Annals of Plant and Soil Research, 17(1): 1-12.

Singh, D. and Singh, V. (1995). Effect of potassium, zinc and sulphur on growth characters, yield attributes and yield of soybean (Glycine max). Ind. J. Agron., 40(2): 223-227.

Singh, Raj and Khan, M. A. (2003). Response of clusterbean varieties to fertility levels and cropping systems under arid conditions. (in) Advances in Arid Legume Research. Henry, A. Kumar, D. and Singh, N. B. (Eds) Scientific Publishers and Indian Society of Arid Legumes, Jodhpur. pp 225-228. 
Singh, S. and Singh, V. (2007). Effect of sources and level of sulphur on yield, quality and nutrient uptake by linseed (Linum usitatissimum Linn.). Indian Journal of Agronomy, 52(2):158-159.

Singh V.K., Singh, T. and Bohra J.S. (2006). Comparative performance of sulphur, seed rate and date of sowing on yield, quality and nutrient uptake in linseed under rainfed conditions of Varanasi region. Crop Research Hissar, 31:63-65.

Singh, U., Tomar, S.S., Rameshwar and Choudhary, S. (2015). Yield, nutrient uptake and economics of indian mustard as influenced by varieties, sources and levels of sulphur. Annals of Plant and Soil Research, 17(3): 266-268.

Solanki, R. L. and Shama, M. (2016). Effect of phosphorus, sulphur and PSB on growth and yield of mustard in Southern Rajasthan. Annals of Plant and Soil Research, 18(1): 66-69.

Sune, S.V., Deshpande, R.M., Khawale, V.S., Baviskar, P.K. and Gurao, B.P. (2006). Effect of phosphorus and sulphur application on growth and yield of linseed. Journal of Soils and Crops, 16(1): 217-221.

\section{How to cite this article:}

Singh, A. K., A. K. Tripathi and Singh, S. R. K. 2020. Response of Potassium and Sulphur in Rabi oilseeds in Kymore Plateau and Satpura Hills Zone of Madhya Pradesh. Int.J.Curr.Microbiol.App.Sci. 9(04): 1215-1226. doi: https://doi.org/10.20546/ijcmas.2020.904.144 